\title{
ЗЕМЕЛЬНІ ВІДНОСИНИ
}

\section{ПОНЯТТЯ ТА СУТНІСТЬ ЗЕМЛЕКОРИСТУВАННЯ ОБОРОНИ В УКРАЇНІ}

Третяк А. М. доктор економічних наук, професор, член-кореспондент НААН України

Мельничук А. Ю., аспірант

Державна екологічна академія післядипломної освіти та управління

E-mail:nnieco@ukr.net

Анотація. Досліджено сутність землекористування оборони в Україні та срормульовано його поняттяя. Встановлено, що регулювання правового режиму більшості різновидів земель оборони на сьогодні відсутнє, а Закон України «Про використання земель оборони» не відповідає своїй назві. У складі підкатегорій земель міністерства оборони за функиіональним використанням виокремлюється сільськогосподарське, лісогосподарське, природоохоронне та містобудівне землекористування. На жаль, землекористування за функиією оборони не виокремлюється. Даний фракт

оцінюеться особливо негативно, званаючи на те, що частина 5 статті 20 земельного кодексу України відсилає саме до зазначеного закону в частині визначення особливостей правового режиму земель оборони. Для земель оборони характерний різний режим їх використання та охорони.

Констатовано, що поняття «землекористування» доцільно розглядати у спорідненості з поняттям «земельна ділянка». У Земельному кодексі України (частина 1 статті 79) під земельною ділянкою розуміється частина земної поверхні з установленими межами, певним місием розташування, з визначеними правами щодо неї. При цьому, «право власності на земельну ділянку розповсюджується на простір, що знаходиться над та під поверхнею ділянки на висоту і на глибину, необхідні для зведення житлових, виробничих та інших будівель і споруд».

Відповідно, в оборонно-безпековому відношенні землекористування оборони являє собою земельний масив, який складається з однієї або кількох земельних ділянок, відмежованих на місцевості, які систематично використовують військові формування $і$ мають особливий режим для забезпечення функціонування їх майнових об'єктів, збереження озброєння, військової техніки та іншого військового майна. Також обгрунтовано, що особливості сутностті землекористування оборони відображуються в його характеристиках як фізичного об'єкта економічних, правових, соціальних, екологічних та оборонно-безпекових земельно-майнових відносин в умовах ринкової економіки.

Ключові слова: землекористування оборони, землі оборони, земельно-майнові відносини. 


\section{Актуальність.}

На зламі тисячоліть проблеми національної безпеки держави вийшли на якісно новий рівень. При цьому силовий (насильницький) спосіб вирішення політичних суперечностей практично залишається безальтернативним. Закінчення епохи «холодної війни» ознаменувалося новим витком воєнного протистояння націй - початком фази «перманентних воєнних конфліктів» та «боротьби 3 тероризмом». Воєнні засоби, створені наприкінці минулого століття для протидії небезпеці індустріального та постіндустріального характеру, виявляються здебільшого малоефективними перед необхідністю подолання викликів та загроз нового походження. Ситуація потребує принципово іншого мислення та дій.

Спостерігається небезпечна тенденція перегляду національних кордонів поза нормами міжнародного права. Застосування сили i погроз силою повернулися до практики міжнародних відносин, у тому числі в Європі. В нових історичних реаліях значно зростає роль Збройних Сил України, які є ядром та головним інструментом забезпечення національної безпеки, і разом 3 іншими військовими формуваннями, органами державної влади та місцевого самоврядування, призначені для відбиття зовнішньої збройної агресії та інших воєнних загроз, пов'язаних із застосуванням військової сили проти України, і для виконання Україною міжнародних зобов'язань.

Роль, місце та завдання Збройних Сил України у забезпеченні обороноздатності держави було закладено ще у 1991 р., коли було ухвалено Закони України "Про Збройні Сили України”, "Про оборону України", уточнені в Конституції України та інших законодавчих документах. На сьогодні Збройні Сили України забезпечують виконання визначених завдань, зокрема щодо відбиття, збройної агресії проти України, прикриття важливих об'єктів держави, угруповань своїх військ від ударів засобами повітряного нападу та ураження військ і об'єктів противника.

3 цією метою вважається за доцільне з урахуванням викликів і загроз національній безпеці держави, iii обороноздатності у найкоротший строк забезпечити вирішення питань і щодо землекористування оборони. Адже ринкова економіка змінила земельно-майнові відносини в державі. Землі оборони мають використовуватися лише в тих межах, які встановила держава.

Мета дослідження - визначення поняття та сутності землекористування оборони в Україні.

\section{Результати досліджень та їх обговорення.}

Останнім часом спостерігається тенденція вивільнення земельних ділянок цієї підкатегорії. Це призвело до нецільового та нераціонального використання земельних та інших природних ресурсів, що просторово розміщенні в межах земельно-майнових комплексів міністерства оборони. Встановлення чітких меж земель оборони і законодавчі механізми регулювання земельних відносин становлять проблему цього дослідження.

Згідно зі статтею 77 «Землі оборони» Земельного кодексу України, землями оборони визнаються землі, які надані для розміщення і постійної діяльності військових частин, установ, військово-навчальних закладів, 
підприємств та організацій Збройних Сил України, інших військових формувань, утворених відповідно до законодавства України [1]. Землі оборони можуть перебувати лише в державній власності. Навколо військових та інших оборонних об>єктів, у разі потреби, створюються захисні, охоронні та інші зони з особливими умовами користування.

Згідно зі статтею 2 Закону України «Про використання земель оборони», військовим частинам для виконання покладених на них функцій та завдань, земельні ділянки надаються у постійне користування відповідно до вимог Земельного кодексу України [2]. Особливості надання земельних ділянок військовим частинам під військові та інші оборонні об〉єкти визначаються Кабінетом Міністрів України. Розміри земельних ділянок, необхідних для розміщення військових частин та проведення ними постійної діяльності, визначаються згідно із потребами на підставі затвердженої в установленому порядку проектно-технічної документації. Військові частини зобов язані використовувати надані їм земельні ділянки відповідно до вимог земельного і природоохоронного законодавства та 3 дотриманням вимог щодо забезпечення безпеки населення у процесі проведення ними постійної діяльності.

Згідно $з$ даними державного земельного кадастру (форма 6-зем), станом на 01.01.16 [3], землі оборони становлять 400,3 га (табл.1) або 0,7\% від території держави, у тому числі міністерство оборони - 339,8 тис. га або 84,7\% від загальної площі земель оборони, міністерство внутрішніх справ 11,8 тис. га, національна гвардія - 10,0 тис. га, державний комітет у справах охорони державного кордону - 6,8 тис. га, товариство сприяння обороні України - 3,1 тис. га, іноземні військові формування - 18,2 тис. га, інші військові формування - 10,7 тис. га.

Як свідчить аналіз даних (табл.1), з 2005 до 2017 р. загальна площа земель оборони зменшилася на 7,4\%, у тому числі земель міністерства оборони на 9,3\%. Як свідчить статистика, законодавство України визначає землі оборони через їх склад, при цьому виходячи фактично із субуєктного складу відносин із використання земель (що, на наш погляд, не узгоджується із положеннями про поділ земель на категорії «за основним цільовим призначенням» ст. 19 ЗКУ).

Як зазначає О. М. Пащенко [5], користувачами земель оборони можуть бути «установи, підприємства, організації і військово-навчальні заклади, які належать таким силовим структурам, як Міністерство оборони, Міністерство внутрішніх справ, Служба безпеки, Адміністрація Державної прикордонної служби, війська Цивільної оборони, а також правоохоронні органи». Такий висновок науковець робить на підставі статті 12 Закону України «Про оборону України», згідно з 1 частиною якої, «участь в обороні держави разом зі Збройними Силами України беруть у межах своїх повноважень також Державна прикордонна служба України, Служба безпеки України, Міністерство внутрішніх справ України, війська Цивільної оборони України, інші військові формування, утворені відповідно до законів України, Державна спеціальна служба транспорту, а також відповідні правоохоронні органи». На думку вченого, 3 огляду на викладене, поняття «землі оборони» та «землі силових структур» потребують чіткого законодавчого визначення. 
1. Характеристика землекористування частин, підприємств, організацій, установ, навчальних закладів оборони станом на 2017 рік

\begin{tabular}{|l|c|c|}
\hline \multirow{2}{*}{ Види використання земель } & \multicolumn{2}{|c|}{ Площа. } \\
\cline { 2 - 3 } & тис. га & $\%$ \\
\hline Міністерства оборони & 339,8 & 85,0 \\
\hline в \% від площіі земель станом на 2005 p. & 90,7 & - \\
\hline Міністерства внутрішніх справ & 11,8 & 2,7 \\
\hline Національної гвардії & 10,0 & 2,5 \\
\hline Державний комітет у справах охорони державного кордону & 6,8 & 1,7 \\
\hline Товариства сприяння обороні України & 3,1 & 0,8 \\
\hline Іноземні військові формування & 18,2 & 4,6 \\
\hline Інші військові формування & 10,7 & 2,7 \\
\hline Всього, тис. га & 400,3 & 100,0 \\
\hline в \% від площі земель станом на 2005 p. & 92,6 & - \\
\hline
\end{tabular}

* Розроблено за даними державного земельного кадастру (форма 6-зем)

Згідно з частиною 2 статті 2 Закону України «Про використання земель оборони» [1], розміри окремих земельних ділянок зі складу земель оборони «визначаються згідно iз потребами на підставі затвердженої в установленому порядку проектно-технічної документації». Разом 3 тим, згідно з положеннями Закону України «Про землеустрій» [5], такою документацією є проекти землеустрою щодо відведення земель.

Частина 2 статті 2 Закону України «Про використання земель оборони» містить вказівку щодо існування особливостей надання земельних ділянок військовим частинам під військові та інші оборонні об'єкти, які мають визначатися Кабінетом Міністрів України. На сьогодні Кабінет Міністрів України таких особливостей не визначив. Натомість, діє наказ Міністра оборони України від 22.12.97 № 483 «Про затвердження «Положення про порядок надання в користування земель (земельних ділянок) для потреб Збройних Сил України та ос- новні правила користування наданими землями» і «Керівництва з обліку земель (земельних ділянок) в органах квартирно-експлуатаційної служби Збройних Сил України».

Таким чином, Закон України «Про використання земель оборони» хоча i прийнятий в розвиток положень статті 77 «Землі оборони» Земельного кодексу України, але практично не має регулятивного значення, оскільки є механічним відтворенням iii положень та викладенням бланкетних норм. Тому, загалом, слід погодитися з О. М. Пащенком у тому, що правове регулювання правового режиму більшості різновидів земель оборони на сьогодні відсутне, а Закон України «Про використання земель оборони» не відповідає своїй назві [4]. Даний факт слід оцінити особливо негативно, зважаючи на те, що частина 5 статті 20 Земельного кодексу України відсилає саме до зазначеного закону в частині визначення особливостей правового режиму земель оборони. 


\section{2. Розподіл земель міністерства оборони за функціональним та дозволеним їх використанням станом на 2017 рік}

\begin{tabular}{|l|c|c|}
\hline \multirow{2}{*}{ Види функціонального та дозволеного використання } & \multicolumn{2}{|c|}{ Площа } \\
\cline { 2 - 3 } & тис. га & \% \\
\hline Сільськогосподарські землі & 47,3 & 13,9 \\
\hline Сільськогосподарські угіддя & 46,9 & 13,8 \\
\hline у т.ч.: рілля & 20,1 & 5,9 \\
\hline багаторічні насадження & 0,1 & - \\
\hline сінокоси і пасовища & 26,7 & 7,8 \\
\hline Під господарськими дворами, шляхами і прогонами & 0,4 & 0,1 \\
\hline Ліси & 125,5 & 36,9 \\
\hline у т.ч.: для виробництва деревини & 55,4 & 16,3 \\
\hline для захисної, природоохоронної та біологічної мети & 36,0 & 10,6 \\
\hline Забудовані землі & 106,0 & 31,3 \\
\hline у т.ч.: житлова & 1,3 & 0,4 \\
\hline промислова & 3,6 & 1,0 \\
\hline відкриті розробки & 0,3 & - \\
\hline громадського призначення & 90,6 & 26,7 \\
\hline змішаного використання & 1,6 & 0,5 \\
\hline транспорту, зв'язку і технічної інфраструктури & 8,5 & 2,5 \\
\hline для відпочинку & 0,1 & - \\
\hline Болота & 3,2 & 0,9 \\
\hline Вода & 1,1 & 0,3 \\
\hline Відкриті землі без рослинного або з незначним рослинним покривом & 56,7 & 16,7 \\
\hline Разом земель & 339,8 & 100,0 \\
\hline З усіх земель природоохоронного призначення & 52,2 & - \\
\hline
\end{tabular}

Законодавчу базу правового інституту земель оборони становлять Земельний кодекс від 25.10.2001 № 2768-III [2], Закон України «Про використання земель оборони» від 27.11.2003 №1345-IV [1], Закон України «Про оборону» від 06.12.1991 №1932-XII [6], Закон України «Про Збройні Сили України» від 06.12.1991 №1934-XII [7], Закон України «Про господарську діяльність у Збройних Силах України» від 21.09.1999 №1076-XIV [8], Закон України «Про правовий режим майна у Збройних Силах України» від 21.09.1999 №1075-XIV [9], Постанова Кабінету Міністрів України від 29.08.2002 р. № 1282 «Про затвердження Порядку вилучення і передачі військового майна Збройних Сил» [10], Постанова Кабінету Міністрів України від 28.12.2000 р. № 1919 «Про порядок відчуження та реалізації військового майна Збройних Сил» [11], Постанова Кабінету Міністрів України від 15.08.2007 p. № 1063 «Деякі питання реалізації та 
управління військовим майном» [12], Постанова Кабінету Міністрів України від 22.05. 2013 р. № 436 «Про затвердження Порядку відчуження земельних ділянок, на яких розташовані об'єкти нерухомого військового майна, що підлягають реалізації, та земельних ділянок, які вивільнюються у процесі реформування Збройних Сил і Державної спеціальної служби транспорту» [13], Розпорядження Кабінету Міністрів України від 21.11.2013 p. № 926-р «Про затвердження переліку земельних ділянок, які можуть бути відчужені разом з розташованими на них об'єктами нерухомого військового майна» [14], Розпорядження Кабінету Міністрів України від 17.07.2015 p. № 740-р «Про затвердження переліку об'єктів нерухомого військового майна, яке може бути відчужено окремо від земельних ділянок» [15], наказ Міністерства оборони «Положення про порядок надання в користування земель (земельних ділянок) для потреб Збройних Сил України...» від 22.12.1997 № 483 [16], наказ Міністерства оборони «Про порядок створення та діяльності комісій з оцінки вартості військового майна..» від 17.09.2001 № 333/1697 [17], Постанова Кабінету Міністрів України «Методика оцінки майна» від 12.12.2003 p. [18] та інші.

Особливістю правового режиму земель оборони $є$ те, що вони можуть перебувати лише в державній та у комунальній (під об'єктами соціально-культурного, виробничого та житлового призначення) власності (частина 2 статті 77, пункт «в» частини 4 статті 84 Земельного кодексу України) [2 ]. Закон України «Про використання земель оборони» [1] передбачає, що землі оборони використовуються відповідними суб'єктами на титулі постійного корис- тування (частина 1 статті 2), проте, стаття 4 кодексу також передбачає можливість надання таких земельних ділянок у вторинне користування для сільськогосподарських потреб: «військові частини за погодженням 3 органами місцевого самоврядування або місцевими органами виконавчої влади і в порядку, визначеному Кабінетом Міністрів України, можуть дозволяти фізичним i юридичним особам вирощувати сільськогосподарські культури, випасати худобу та заготовляти сіно на землях, наданих їм у постійне користування».

Отже, для земель оборони характерний різний режим їх використання та охорони. У табл. 2 подано характеристику земель Міністерства оборони за функціональним та дозволеним їх використанням.

Згідно 3 даними, викладеними в табл. 2, у складі підкатегорії земель міністерства оборони за функціональним використанням виокремлюється сільськогосподарське, лісогосподарське, природоохоронне та містобудівне землекористування. На жаль, землекористування за функцією оборони не виокремлюється.

Коротко зупинимося на понятті та сутності землекористування. Поняття «землекористування» доцільно розглядати у спорідненості з поняттям «земельна ділянка». У Земельному кодексі України (частина 1 статті 79) під земельною ділянкою розуміється частина земної поверхні з установленими межами, певним місцем розташування, з визначеними правами щодо неї. При цьому, «право власності на земельну ділянку розповсюджується на простір, що знаходиться над та під поверхнею ділянки на висоту й на глибину, необхідні для зведення житлових, виробничих 
та інших будівель і споруд». Отже, в Україні землекористування та землеволодіння, відповідно до статті 79 Земельного кодексу, включає систему таких понять [2]:

- земельна ділянка як частина земної поверхні із встановленими межами, певним місцем розташування, 3 визначеними щодо неї правами;

- право власності, володіння та користування на таку земельну ділянку поширюється в їі межах на поверхневий (грунтовий) шар, а також на водні об'єкти, ліси і багаторічні насадження, які на ній знаходяться;

- право власності, володіння та користування на таку земельну ділянку, на відміну від інших країн світу, розповсюджується на простір, що знаходиться над і під поверхнею ділянки на висоту і на глибину, необхідні для зведення житлових, виробничих та інших будівель і споруд.

Особливості здійснення землекористування залежать від цільового призначення землі. У сучасних умовах поняття землекористування набуло суттєво глибшого економічного змісту. Так, А. М. Третяк вважає, що поняття землекористування необхідно розглядати як економічну категорію, оскільки в економічних відносинах функціонування землі в процесі виробництва може бути як раціональним, так і нераціональним; як ефективним, так і неефективним [19]. Таке визначення суті землекористування, як зазначає В. М. Другак [20, с. 6], тільки з матеріально-речового боку має важливе значення у багатьох галузях знань, але явно недостатнє і далеко не вичерпує всієї сукупності ознак, властивих його змісту. У теорії та практиці слід розрізнювати поняття землекористування як матеріального (фізичного) об'єкта i комплексу соціальних, економічних, містобудівних, сільськогосподарських, екологічних, правових та інших відносин, які забезпечують спеціальний порядок використання, володіння і в окремих випадках розпорядження земельною ділянкою та особливу стійкість прав (рис. 1).

Наприклад, при використанні землі в сільському господарстві землекористування об'єднує часом десятки або й сотні земельних ділянок власників земельних часток (паїв), земельні ділянки спільної власності, меліоративні та інші комплекси. Таким чином, землекористування має ширше поняття ніж земельна ділянка. Разом $з$ тим, термін «землекористування» застосовують у науковій літературі в подвійному значенні [21]. Під землекористуванням розуміють систему користування землею, регламентовану законодавством для різних категорій земель, власників землі та землекористувачів. Термін «землеко-

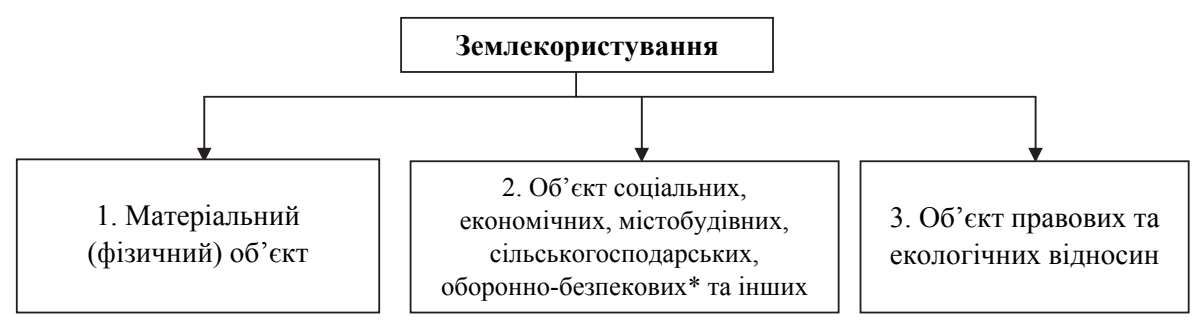

Рис. 1. Логічна схема поняття землекористування [20, с. 7]

* Доповнено автором 
ристування» означає земельний масив, територію, що перебуває у власності чи користуванні. Так, згідно 3 Українською радянською енциклопедією (1979 р.), «землекористування - це земля, що надається в користування громадським організаціям, установам, колгоспам і громадянам у безплатне й безстрокове користування. Порядок і правила користування землями залежить від їх цільового призначення» [22].

Таким чином, як констатує В. М. Другак, землекористування визначається в трьох аспектах [23]: 1) як користування землею в установленому законом порядку (земельна ділянка); 2) як частина єдиного земельного фонду, що надана державою або набута у власність чи оренду окремим користувачем для господарської або іншої мети, обмежена на місцевості; 3) як об'єкт права, об'єкт економічних, екологічних, містобудівних, сільськогосподарських та інших земельних відносин, на який землекористувачу видано документ, що посвідчує право на землю 3 визначеними межами, площею, складом угідь, майнових об'єктів та, за потреби, з геодезичними координатами межових знаків, що визначені в натурі. На рис. 2 наведено порівняльну характеристику сутності землекористування в контексті фізичного об'єкта, економічних, правових, соціальних та екологічних відносин $[20$, с. 8], яку ми доповнили оборонно-безпековими аспектами.

Разом 3 тим, як зазначає А. М. Третяк та В. М. Другак, формування землекористування і його функціонування має низку особливостей. Земля виступає як територіально-обмежений ресурс. Територіальна обмеженість зумовлює монополію на землю, як об'єкт власності та об'єкт господарювання. Як об'єкт власності земля менш доступна через високу вартість. Як об’єкт господарювання земля більш доступна і приваблива. Тому в розвиненому економічному суспільстві виникає конкуренція 3 приводу використання визначеної земельної території, а у землевласника 3'являється кілька варіантів оформлення земельної ділянки на різних правах власності [23, 195].

Отже, поняття землекористування доцільно розглядати в природному, правовому, економічному, екологічному, оборонно-безпековому та інших аспектах. Де, на думку В. М. Другак, у природному відношенні землекористування являє собою земельний масив, який складається 3 однієї або кількох земельних ділянок, відмежованих на місцевості, які систематично використовують у різних галузях економіки або потенційно мають умови для такого використання [23].

В оборонно-безпековому відношенні землекористування оборони являє собою земельний масив, який складається $з$ однієї або кількох земельних ділянок, відмежованих на місцевості, які систематично використовують військові формування і мають особливий режим для забезпечення функціонування їх майнових об'єктів, збереження озброєння, військової техніки та іншого військового майна.

Військові частини використовують закріплені за ними земельні ділянки і військове майно, що розміщене на них, лише за цільовим та функціональним призначенням. Згідно 3 «Класифікацією видів цільового призначення земель», [25] у категорії земель оборони (розділ 15) виділяється таке цільове їх призначення: підрозділ 15.1 - для розміщення та постійної 


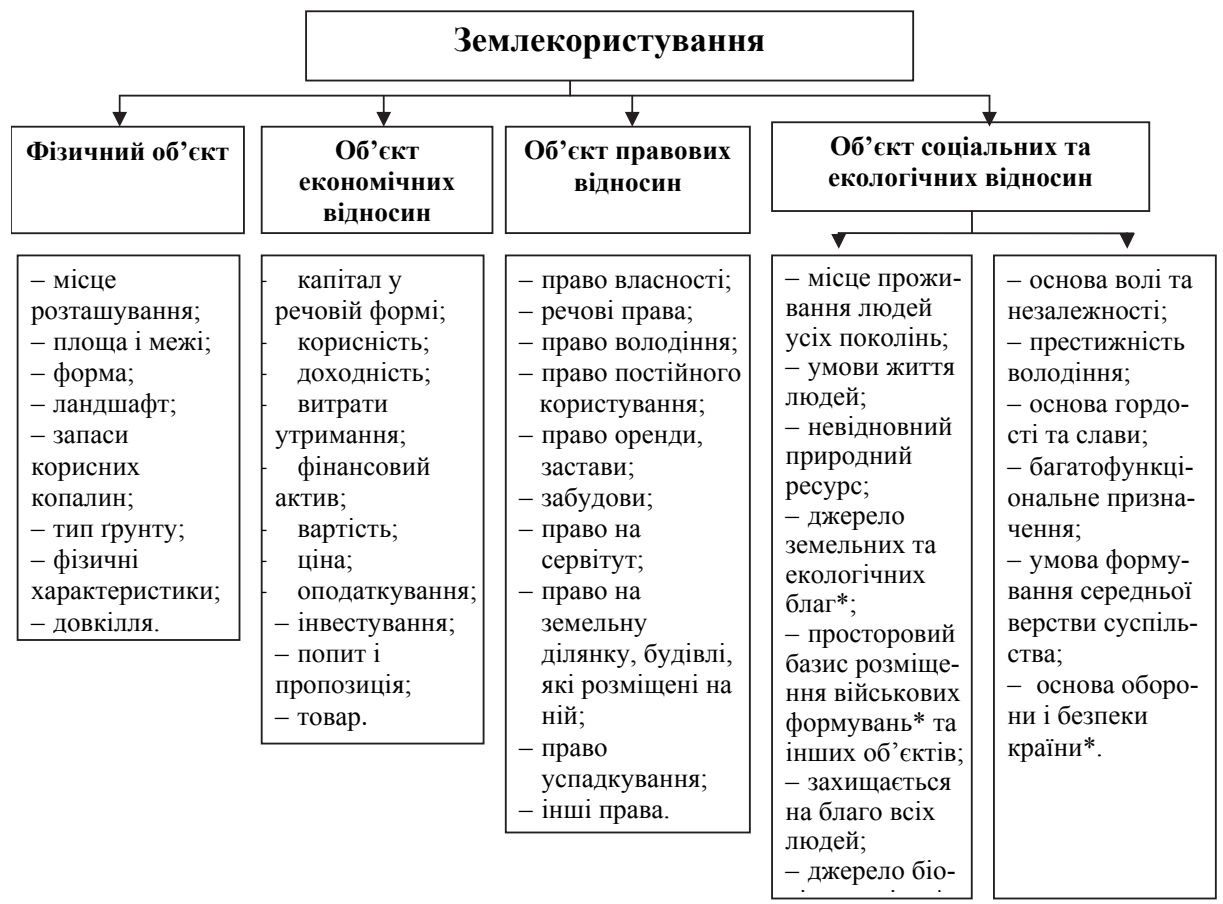

Рис. 2. Характеристика землекористування як фізичного об'єкта, економічних, правових, соціальних, екологічних та оборонно-безпекових відносин [20, с. 8, 24, с. 19]

* Доповнено автором

діяльності Збройних Сил України; підрозділ 15.7 - для розміщення та постійної діяльності інших, створених відповідно до законів України військових формувань; підрозділ 15.8 - для цілей підрозділів; 15.01-15.07, $15.09,15.10$ - для збереження та використання земель природно-заповідного фонду. Разом з тим, розміщення і обслуговування військового майна та специфічної господарської діяльності [26] потребує й іншого цільового призначення земель.

Законодавство України визначає особливим видом суб'єктів земельного права суб'єктів господарської діяльності з особливим режимом використання земель у Збройних Силах України. Особливий режим викори- стання земель, відповідно до частини 3 статті 77 Земельного кодексу України, передбачене зовнішне зонування земель - створення навколо оборонних обуєктів захисних, охоронних та інших зон з особливими умовами користування. Проте, спеціальний Закон України «Про використання земель оборони» лише відтворив це положення, не конкретизувавши режиму відповідних зон та порядку їх встановлення.

\section{Висновки і перспективи.}

Землекористування оборони - це земельні масиви, які складаються 3 однієї або кількох земельних ділянок, відмежованих на місцевості, які систематично використовують військові 
формування i мають особливий режим для забезпечення функціонування їх майнових об〉єктів, збереження озброєння, військової техніки та іншого військового майна.

Особливості сутності землекористування оборони відображуються в його характеристиках як фізичного об'єкта, економічних, правових, соціальних, екологічних та оборонно-безпекових земельно-майнових відносин в умовах ринкової економіки.

\section{Список використаних джерел:}

1. Про використання земель оборони : закон України [Електронний ресурс] // Відомості Верховної Ради України. - 2004. - Режим доступу : http://zakon2. rada.gov. ua/laws/show/1345-15

2. Земельний Кодекс України [Електронний ресурс] // Відомості Верховної Ради України.-2002.-Режим доступу: http://zakon2. rada.gov.ua/laws/show/2874\%D0\%B0-07

3. Державний земельний кадастр (форма 6-зем) станом на 01.01.2016 р. Держгеокадастр України.

4. Пащенко О. М. Особливості правового режиму земель оборони / О. М. Пащенко // Земельне право України: теорія і практика. - 2007. - № 1. - С. 32-36.

5. Про землеустрій : закон України [Електронний ресурс] // Відомості Верховної Ради України. - 2003. - Режим доступу : http://zakon2.rada. gov.ua/laws/ show/858-15/print1476586411943513

6. Про оборону : закон України [Електронний ресурс] // Відомості Верховної Ради України. - 1992. - Режим доступу : http:// zakon0.rada.gov.ua/ laws/show/1932-12/ print1510080742877383

7. Про Збройні Сили України : закон України [Електронний ресурс] // Відомості Верховної Ради України. - 1992. - Режим доступу : http://zakon2.rada. gov. ua/laws/show/1934-12
8. Про господарську діяльність у Збройних Силах України : закон України [Електронний ресурс] // Відомості Верховної Ради України. - 1999. - Режим доступу : http:// zakon5.rada.gov.ua/laws/show/1076-14

9. Про правовий режим майна у Збройних СилахУкраїни» : закон України [Електронний ресурс] // Відомості Верховної Ради України. - 1999. - Режим доступу : http:// zakon3.rada.gov.ua/laws/show/1075-14

10. Про затвердження Порядку вилучення і передачі військового майна Збройних Сил : постанова Кабінету Міністрів України [Електронний ресурс]. - 2002. - Режим доступу : http://zakon3.rada.gov.ua/ laws/show/1282-2002-\%D0\%BF

11. Про порядок відчуження та реалізації військового майна Збройних Сил : постанова Кабінету Міністрів України [Електронний ресурс]. - 2000. - Режим доступу : http://zakon3.rada.gov.ua/laws/ show/1919-2000-\%D0\%BF

12. Деякі питання реалізації та управління військовим майном : постанова Кабінету Міністрів України [Електронний ресурс]. 2007. - Режим доступу : http://zakon4.rada. gov.ua/laws/show/1063-2007-\%D0\%BF

13. Про затвердження Порядку відчуження земельних ділянок, на яких розташовані об'єкти нерухомого військового майна, що підлягають реалізації, та земельних ділянок, які вивільнюються у процесі реформування Збройних Сил : постанова Кабінету Міністрів України № 436 [Електронний ресурс]. - 2013. - Режим доступу : http://zakon2.rada. gov.ua/laws/ show/436-2013-\%D0\%BF

14. Про затвердження переліку земельних ділянок, які можуть бути відчужені разом з розташованими на них об'єктами нерухомого військового майна : розпорядження Кабінету Міністрів України № 926-р [Електронний ресурс]. - 2013. - Режим доступу : http://zakon5.rada.gov.ua/ laws/show/926-2013-\%D1\%80

15. Про затвердження переліку об'єктів нерухомого військового майна, яке може бути 
відчужено окремо від земельних ділянок : розпорядження Кабінету Міністрів України № 740-р [Електронний ресурс]. - 2015. - Режим доступу : http://zakon3. rada.gov.ua/laws/show/740-2015-\%D1\%80

16. Положення про порядок надання в користування земель (земельних ділянок) для потреб Збройних Сил України : наказ Міноборони № 483 [Електронний ресурс]. - 1997. - Режим доступу : https://ips.ligazakon.net/ document/ view/ fin35028?an $=82$

17. «Про порядок створення та діяльності комісій з оцінки вартості військового майна..» : наказ Міноборони [Електронний ресурс]. - 2001. - Режим доступу : http://zakon.rada.gov.ua/laws/show/ z0871-01

18. Методика оцінки майна : постанова Кабінету Міністрів України № 1891 [Електронний ресурс]. - 2003. - Режим доступу : http://zakon.rada.gov.ua/ laws/ show/1891-2003-\%D0\%BF

19. Третяк А. М. Екологія землекористування: теоретико-методологічні основи формування та адміністрування : монографія / А. М. Третяк. - Херсон, 2012. 438 с. - (Грінь Д. С.). - С. 13-14.

20. Другак В. М. Теоретичні та методичні основи економіки землекористування / В. М. Другак. - К. : ЦЗРУ, 2004. - 129 с.

21. Нестеров Ю. В. Практичні поради зі збереження біорізноманіття у сільськогосподарських угіддях / Ю. В. Нестеров. - K. : Wetlands International Black Sea Programme, 2005. - 48 c.

22. Українська радянська енциклопедія. - К. : Наукова думка, 1979. - 659 с.

23. Другак В. М. Економіка сільськогосподарського землекористування: теорія, методологія та практика : дис. ... доктора екон. наук : 08.00.06 / Другак Валентина Миколаївна. - К., 2010. - 461 с.

24. Лобунько Ю. В. Формування природоохоронного землекористування в умовах нових земельних відносин : дис. ... канд. екон. наук / Лобунько Ю. В. - Київ, 2006. - 235 c.

25. Класифікація видів цільового призначення земель : наказ Державного комітету України із земельних ресурсів № 548 [Електронний ресурс]. - 2010. - Режим доступу : http://zakon2.rada.gov.ua/laws/ show/z1011-10

26. Про затвердження переліку видів господарської діяльності, здійснення якої дозволяється військовим частинам Збройних Сил : постанова Кабінету Міністрів України № 1171. - Кабінет Міністрів України [Електронний ресурс]. - 2000. Режим доступу : http://zakon5.rada.gov. ua/laws/show/1171-2000-п

\section{References}

1. The Law of Ukraine "Use of Land of Defense (2004). Available at: http://zakon2.rada. gov.ua/laws/show/134.

2. Land Code of Ukraine (2002). Available at: http://zakon2.rada.gov.ua/ᄀlaws/ show/2874\%D0\%B0-07.

3. State Land Cadastre (Form 6-Land) (01.01.2016).

4. Pashchenko O. M. (2007) Osoblyvosti pravovoho rezhymu zemel oborony. Zemelne pravo Ukrainy: teoriia i praktyka. [Features of the legal regime of lands of defense Land law of Ukraine: theory and practice]. №1, 32-36.

5. Law of Ukraine "Land Management" (2003). Available at: http://zakon2. rada.gov.ua/laws/show/858-15/ print1476586411943513.

6. The Law of Ukraine "On Defense" (1992). Available at: http://zakono. rada.gov.ua/laws/show/1932-12/ print1510080742877383.

7. Law of Ukraine "The Armed Forces of Ukraine" (1992). Available at: http://zakon2.rada.gov.ua/laws/show/1934-12.

8. The Law of Ukraine "On Economic Activity in the Armed Forces of Ukraine» (1999). 
Available at: http://zakon5.rada.gov.ua/ laws/show/1076-14.

9. The Law of Ukraine "The Legal Status of Property in the Armed Forces of Ukraine" (1999). Available at: http://zakon3.rada. gov.ua/laws/show/1075-14.

10. Resolution of the Cabinet of Ministers of Ukraine "Approval of the Procedure for the Seizure and Transfer of Military Property of the Armed Forces" (2002). Available at: http://zakon3.rada.gov.ua/ laws/show/1282-2002-\%D0\%BF.

11. Resolution of the Cabinet of Ministers of Ukraine "On the Procedure of Alienation and Sale of Military Property of the Armed Forces" (2000). Available at: http://zakon3.rada.gov.ua/laws/show/1919-2000\%D0\%BF.

12. Resolution of the Cabinet of Ministers of Ukraine "Some Issues in the Realization and Management of Military Property" (2007). Available at: http://zakon4.rada. gov.ua/laws/show/1063-2007-\%D0\%BF.

13. Resolution of the Cabinet of Ministers of Ukraine Approval of the Procedure for Alienation of Land Plots in which Real Estate Military Property Objects Subject to Realization and Land Plots Released in the Process of the Reform of the Armed Forces and the State Special Transport Service are located. (2013). Available at: http:// zakon2.rada.gov.ua/laws/show/436-2013\%D0\%BF.

14. Order of the Cabinet of Ministers of Ukraine "Approval of the list of land plots that can be alienated together with 3 objects of immovable military property located on them" (2013). Available at: http:// zakon5.rada.gov.ua/laws/show/926-2013$\% \mathrm{D} 1 \% 80$.

15. Order of the Cabinet of Ministers of Ukraine "Approval of the list of objects of immovable military property that may be alienated separately from land plots." (2015). Available at: http://zakon3.rada. gov.ua/laws/show/740-2015-\%D1\%80.
16. Order of the Ministry of Defense "Regulation on the procedure for the use of land (land plots) for the needs of the Armed Forces of Ukraine" №483 (1997). Available at: https://ips.ligazakon.net/document/ view/fin35028?an=82.

17. Order of the Ministry of Defense "The Procedure for the Establishment and Operation of Commissions for the Estimation of the Cost of Military Property" (2001). Available at: http://zakon.rada.gov.ua/ laws/show/z0871-01.

18. Resolution of the Cabinet of Ministers of Ukraine "Methodology of valuation of property" №1891 (2003). Available at: http:// zakon.rada.gov.ua/laws/show/1891-2003\%D0\%BF.

19. Tretiak A. M. (2012). Ekolohiia zemlekorystuvannia: teoretyko-metodolohichni osnovy formuvannia ta administruvannia [Ecology of land use: theoretical and methodological foundations of formation and administration]. Kherson, 438.

20. Druhak V. M. (2004). Teoretychni ta metodychni osnovy ekonomiky zemlekorystuvannia [Theoretical and methodological principles of land use economics]. Kyiv, 129.

21. Nesterov Yu. V. (2005). Praktychni porady zi zberezhennia bioriznomanittia u silskohospodarskykh uhiddiakh [Practical tips on biodiversity conservation in agricultural lands]. Kyiv, Wetlands International Black Sea Programme, 48.

22. Ukrainska radianska entsyklopediia. (1979). [Ukrainian Soviet Encyclopedia]. Naukova dumka, $659 \mathrm{~s}$.

23. Druhak V. M. (2010). Ekonomika silskohospodarskoho zemlekorystuvannia: teoriia, metodolohiia ta praktyka [Economics of Agricultural Land Use: Theory, Methodology and Practice]. Kyiv, 461.

24. Lobunko Yu. V. (2016). Formuvannia pryrodookhoronnoho zemlekorystuvannia $v$ umovakh novykh zemelnykh vidnosyn [Formation of protected land use in conditions of new land relations]. Kyiv, $235 \mathrm{~s}$. 
25. Classification of types of land intended for use was approved by the order of the State Committee of Ukraine for Land Resources № 548 (2010). Available at: http://zakon2. rada.gov.ua/laws/show/z1011-10.

26. Approval of the list of types of economic activity, the implementation of which is allowed military military units of the Armed Forces, №1171 (2000). Available at: http:// zakon5.rada.gov.ua/laws/show/11712000-p.

\section{$* * *$ \\ Tretyak A., Melnichuk A. \\ THE CONCEPT AND ESSENCE OF LAND- USE DEFENSE IN UKRAINE \\ https://doi.org/10.31548/ \\ zemleustriy2018.03.03}

Abstract. Researched the essence of land use of defense in Ukraine and formulated its definition. Installed that the regulation of the legal regime of most types of land of defense is absent today, and the Law of Ukraine "On use of lands of defense" doesn't respond to its name. In the subcategories of the land of the Ministry of Defense, for functional use, agricultural, forestry, nature conservation and urban land use are allocated. Unfortunately, land use is not allocated to the defense function, but part 5 of Article 20 of the Land Code of Ukraine refers precisely to the said law in terms of determining the peculiarities of the legal regime of land defense.

The peculiarity of the legal regime of the land of defense is that they can be only state or communally owned (under the objects of socio-cultural, industrial and residential purposes) property (Article 2, part 2, paragraph " $\mathrm{C}$ ", paragraph 4 of Article 84 of the Land Code of Ukraine ) [2]. The Law of Ukraine "On use of land of defense" [1] provides that land use by the relevant subjects in the title of permanent use (Article 2 (1), but also provides (Article 4) the possibility of granting such land plots for secondary use for agricultural purposes : "military units, in coordination with local executive bodies or authorities and according to they procedure determined by the Cabinet of Ministers of Ukraine, can permit natural persons and legal persons to grow crops, graze livestock and (harvested) hay on land provided to them for permanent use".

Analysis of scientific works shows that the concept of land use should be considered in the natural, legal, economic, environmental, defense and security and other aspects. In sense defense and security terms, land-use of defense is a land mass, which consists of one, or several land plots separated on the ground, which are systematically used by military units and have a special regime to ensure the functioning of their properties, the storage of weaponry and military equipment.

Consequently, land-use defense is a land mass, which consists of one, or several land plots isolated on the ground, which systematically use military formations and have a special regime for ensuring the functioning of their property objects, the preservation of weapons, military equipment and other military property. The essence of land use of defense is reflected in its characteristics as a physical object, economic, legal, social and environmental defense-security land-property relations in a market economy.

Keywords: land use of defense, land of defense, land and property relations.

\section{*** \\ Третяк А. М., Мельничук А. Ю. ПОНЯТИЕ И СУЩНОСТЬ ЗЕМЛЕ- ПОЛЬЗОВАНИЯ ОБОРОНЫ В УКРАИНЕ \\ https://doi.org/10.31548/ \\ zemleustriy2018.03.03}

Аннотация. Исследована сущность землепользования обороны в Украине и сформулировано его понятие. Установлено, что регулирование правового режима большинства разновидностей земель обороны на сегодня отсутствует, а Закон Украины "Об использовании земель обороны» не соответствует своему названию. В составе подкатегории земель министерства обороны по функциональному использованию 
выделяется сельскохозяйственное, лесохозяйственное, природоохранное и градостроительное землепользование. К сожалению, землепользование по функции обороны не выделяется. Данный факт оценивается особенно негативно, несмотря на то, что часть 5 статьи 20 Земельного кодекса Украины отсылает именно к указанному закону в части определения особенностей правового режима земель обороны. Для земель обороны характерен различный режим их использования и охраны.

Констатировано, что понятие «землепользование» целесообразно рассматривать в родстве с понятием «земельный участок». В Земельном кодексе Украины (часть 1 cmamьи 79) под земельным участком понимается часть земной поверхности с установленными границами, определенным местом расположения, с определенными правами в отношении нее. При этом, «право собственности на земельный участок распространяется на пространство, находящееся над и под поверхностью участка на высоту и на глубину, необходимые для возведения жилых, производственных и других зданий и сооружений».

Соответственно, в оборонно-безопасном отношении землепользование обороны представляет собой земельный массив, состоящий из одного или нескольких земельных участков, ограниченных на местности, которые систематически используют военные формирования и имеют особый режим для обеспечения функционирования их имущественных объектов, сохранения вооружения, военной техники и другого военного имущества. Также обосновано, что особенности сущности землепользования обороны отражаются в его характеристи ках как физического объекта экономических, правовых, социальных, экологических и оборонно-безопасных земельно-имущественных отношений в условиях рыночной экономики.

Ключевые слова: землепользование обороны, земли обороны, земельно-имущественные отношения. 